\title{
Oppiminen, tieto ja toiminta
}

Maikki Kaajakari (1983) kirjoitti viime numerossa kriittisiă kommentteja kirjastani 'Perustietoa opetuksesta' (Engeström 1982). Keskustelu on tarpeen ja jatkan sită tăssă. Kaajakari păătti siirtăă kirjan pois kăsistăăn ja kirjoittaa vaikutelmistaan. Minäkäăn en pitäydy kirjan tekstiin, vaan kirjoitan ajatuksistani.

Kaajakari nostaa kirjoituksessaan esiin neljă ongelmaa: ensinnäkin kysymyksen tiedon luonteesta, toiseksi kysymyksen opettamisen luonteesta, kolmanneksi kysymyksen opiskelijan elämänkokemuksen merkityksestä opetusoppimisprosessissa ja neljänneksi kysymyksen toiminnan teorian ja kognitiivisen psykologian suhteesta. Hahmottelen omia ajatuksiani näiden neljän kysymyksen mukaisessa järjestyksessä. Mainittakoon, ettă saman tapaista keskustelua on äskettăin kăyty myős Koulutyöntekijă-lehdessă (Engestrơm 1983d; Kuure 1983).

\section{Mitä on tieto?}

Kaajakari arvelee, ettă arvostan tietona vain loogista, jăsentynyttă, yksiselitteistă tietorakennetta. Kuitenkaan opetuksessa käsiteltävăt asiat eivăt lăheskäăn aina ole tăllaisia, vaan ristiriitaisia, prosessinomaisia, keskeneräisiă. "Ken kykenee elävăn elămăn toimintaperiaatteen 'oikein' hahmottamaan?'” (Kaajakari 1983, 31.)

Mielestäni tarvitaan kaksi askelta, jotta păăstăisiin asian ytimeen suhtautumisessa tietoon. Ensimmäinen askel on pinnallisen, kuvailevan ja luetteloivan, muodollisia măăritelmiă jakelevan, erillisistă sirpaleista koostuvan tiedon kritiikki. Tăstă seuraa vaatimus jăsentyneiden rakenteiden ja selittăvien periaatteiden muodostamisesta. Tămă vaatimus on ominainen oppimisen ja opetuksen kognitiiviselle psykologialle, ja se on painokkaasti esitetty myös kirjassani. Kovin usein mm. aikuisopetuksessa vetoaminen elămyksellisyyteen, demokraattisuuteen ja luovuuteen merkitsee kăytănnơssă sită, ettă opettaja ei yrităkăăn lơytăă opetettavan aiheen kantavia periaatteita ja kăsitteită, eikă tuloksena ole opiskelijoiden reaalisen ympäristönhallinnan lisääntyminen vaan monesti pettăvă hyvănolontunne.
Mutta toisena askeleena tarvitaan tiedon ristiriitaisuuden ja prosessiluontoisuuden käsittämistă. Tăhăn ei păästă pelkällă eläytymisellă ja avoimuudella, vaan tarvitaan entistăkin kehittyneempiă ajattelun tyőkaluja, pureutumista syvemmälle asioiden sisältőőn. Kirjassani korostan, ettă keskeinen keino tăssă on asioiden tarkasteleminen historiallis-geneettisesti, siis ilmiöiden ja olioiden syntyperustan ja kehityksen jäljittăminen. Kaajakari toteaa oikein, ettă monet opetettavat asiat ovat ristiriitaisia ja prosessiluontoisia. Oikeammin: kaikki opetettavat asiat ovat pohjimmiltaan sellaisia. Mutta silti niită on pyrittävă ymmärtămăăn ja hallitsemaan, tietoisena oman hallinnan rajallisuudesta. Ymmärtäminen ja hallitseminen edellyttăă olettamusten tekoa asiakokonaisuuksien olemuksesta, niiden 'alkusolujen' muodostamista, kehittelyă ja koettelua. "Niillă on laaja siirtovaikutus, niiden avulla voidaan ymmärtăă ja hallita periaatteessa rajaton măără uusia yksittăisongelmia ja ilmiöită. Tăssă mielessă ne tuottavat uutta tietoa eli mahdollistavat luovan toiminnan." (Engeström 1982, 39.)

Juuri tămă toinen askel on keskeinen toiminnan teoriaan perustuvassa oppimiskăsityksessä (vrt. Dawydow 1977). Tavallaan tămă toinen askel merkitsee ensimmäiseen askeleeseen sisăltyvăn 'varmuuden' ja 'selkeyden' kieltămistä. Mutta kyse ei ole paluusta sekavuuteen ja năennäistietoon, vaan 'pysăhtyneenă' käsitetyn tiedon ylittămisestă, tiedon kăsittämisestă tekoina ja toimintana, joilla muokataan maailmaa, kokeillaan ja kehitelläăn todellisuutta. Näin ymmärretty tieto on nimenomaan prosessi, mutta lainomainen ja tietoinen 'abstraktista konkreettiseen kohoamisen prosessi', jota olen kuvannut kirjan sivulla 118 olevalla kaaviolla.

Käytännössă tămă toinen askel merkitsee, ettă myős epăvarmoissa, kiistanalaisissa ja elămyksellisissă asioissa etsităăn niiden syntyă, alkuperăă ja sisăisiă suhteita (mielestäni tămă sopii erityisen hyvin taideaineiden opetukseen). Väittely, vastakkaisten tulkintojen palauttaminen juuriinsa, palvelee usein tătă tarkoitusta. Vastaavasti näennäisen varmoissa ja kiistattomissa asioissa on tarpeen lơytăă niiden sisäinen ristiriitaisuus ja dynamiikka. 


\section{Mitä on opettaminen?}

Kaajakari arvelee, ettă năen opetuksen valmiin, yksiselitteisen tiedon tehokkaana vălittämisenă oppilaille. Kaajakari suosittaa, ettă opettaja ottaisi oppijan 'matkalle mukaan seuraamaan ajatuksenjuoksua, vaihtoehtoisten lähestymistapojen pohdintaa, valmistautumisen yhteydessă tehtyjă valintoja" (s. 31).

Mielestäni matkalle mukaan seuraaminen ei riită. Kirjassani esităn: "Opiskelua voidaan parhaimmillaan verrata löytöretkeilijăn työhơn. Opiskelija valloittaa tuntemattomia tiedon ja taidon alueita. (...) Opettajan tulee tehdă oppilaista loytőretkeilijoită."' (s. 93.) Toisin sanoen oppilaat tulisi itse saada kokeilujen ja kăytănnöllisen ongelmanratkaisun avulla muodostamaan tutkittavaa asiakokonaisuutta selittăvă 'alkusolu' sekă edelleen konkreettisissa tehtävissă kehittelemäăn, rikastamaan ja testaamaan selitysmalliaan.

Luulen, ettă Kaajakarin ja minun ajatteluni ero on siină, ettă pyrin koko ajan siihen että oppilaat todella omaksuvat ja oppivat käyttämäăn joitakin sisăllobllisiă käsitteită, ajattelun työkaluja, 'alkusoluja'. Sen sijaan saan sen vaikutelman, ettă Kaajakarille riittăă, ettă oppija "punnitsee ja tarkkailee omaa muotoutuvaa suhdettaan" aiheeseen (s. 31-32). Aavistelen, ettă Kaajakari pităă oppimista aika pitkălle oppijan päăssä tapahtuvana itsetiedostuksena, havaintojen ja elămănkokemusten uudelleenjäsentymisenă keskustelussa ja pohdinnassa. Minulle oppiminen on paljon enemmăn yhteiskunnallisten esinemerkityksien omaksumista aineellisten, esineellisten tekojen ja todellisuuden muuttamisen kautta: siis reaalisen ympäristönhallinnan laajentamista ja syventămistă. Tăstă seuraa erilainen painotus opettamisen luonnehdinnassa.

Olen kyllă samaa mieltă siită, ettă opettajakaan ei aina voi tietăă oppimisen lopputulosta. Uusia todellisuuden selittämisen ja hallinnan malleja voidaan todella tuottaa kollektiivisesti opetus-oppimisprosessissa. Mutta tämă ei mielestäni vapauta opettajaa esim. pelkkien muodollisten menettelytapatietojensa avulla 'edesauttamaan etenemistă'. Opettaja, joka ei perehdy opittavaan sisăltőờn eikă nosta menettelytapoja (so. ratkaistavia tehtäviă, käytettăviă menetelmiă) tuon sisällön omasta logiikasta, on kovin lähellă sită itsepetoksen kierrettă, johon moni yritysmaailman konsultti ja kouluttaja on ajautunut.

\section{Mikä on opiskelijoiden elämänkokemuksen merkitys?}

Kaajakari painottaa opiskelijoiden elămănkokemuksia yhtälülă oppimisprosessin tiedonlăhteenă, toisaalta kaiken uuden omaksumisen 'suodattimena'.

Pidăn myős oppilaiden elămănkokemuksia tärkeănă tiedonlähteenă opetuksessa. Mutta kokemukselle ja arkitiedolle on ominaista ristiriitaisuus. Esimerkiksi ammattiyhdistysliikkeen kouluttajat toteavat yhă uudelleen, ettă pelkästäăn ay-aktiivien omasta kokemuksesta lăhtevă opetus ei riită esim. työprosessien kehityksen vaihtoehtojen hahmottamiseen, vaikka juuri kentăn aktiivien kokemustieto työn kehityksestă on toisaalta korvaamatonta vaihtoehtojen kehittelyssă. Tämă tulee monin tavoin esiin toimittamani SAK:n Ammattiyhdistysopiston raportin 'Automaatio - ammattitaito - tietoisuuden kehitys' (Engeström 1983a) artikkeleissa.

Jos kokemus uuden tiedon suodattimena otetaan kaiken opetuksen hallitsevaksi lăhtökohdaksi, ollaan nopeasti tilanteessa, jossa opetus vain vahvistaa arkikäsityksiin sisăltyviă harhoja ja rajoituksia. Kokemus vahvistaa meille päivittăin senkin, ettă maa on litteă ja aurinko kiertăă maata. Toisaalta tyőtătekevăn ihmisen kokemus antaa viitettă siitä, ettă monimutkaisetkin asiat voidaan kăsittăă ja hallita, kun niită păăstăăn kăsittelemăăn oikeilla tyőkaluilla. Tătă jălkimmăistă, dynaamista puolta arkikokemuksessa tarvitaan pontimena edellisen, vastaanottavan ja harhaisen puolen ylittămiseksi.

\section{Toiminnan teoria ja kognitiivinen psykologia}

Kaajakari on oikeassa todetessaan, ettă toiminnan teorian ja kognitiivisen psykologian vălillă on jănnite. Hăn on văărăssă arvellessaan, ettă kirjassani toiminnan teorialla on ehdoton yliote. Tilanne on miltei päinvastainen. Kirjassa painottuu vielă vahvasti alussa mainitsemani ensimmäinen askel tiedon uudelleenarvioinnissa. Toiminnan teoria esiintyy kirjassa paljolti vasta ituina.

Năyttăă siltă, ettă Kaajakari năkee toiminnan teorian ahtaasti uusien tietojen sisäistämisen teoriaksi. Toiminta pelkistyy tălloin opettajan antamien ohjeiden ja ehtojen puitteissa tapahtuvaksi 'suppeaksi aktiiviseksi toimin- 
naksi' (s. 32). Paradoksaalista kyllä, tămă on nimenomaan tunnusmerkillinen näkemys suurelle osalle kognitiivisen psykologian opetuksellisia sovelluksia. Oppiminen rajataan niissä luokkahuoneen sisällă tapahtuvaksi verbaalisen oppimateriaalin mentaaliseksi 'elaboroinniksi'. Tăstä olen laatinut kriittisen katsauksen, joka ilmestyy Psykologia-lehden numerossa 3/1983 (Engeström 1983b). Kăsittelen asiaa myős Vapaan sivistystyön vuosikirjassa 1983 (Engeström 1983c).

Kaajakarin käsitys toiminnan teoriasta kaipaa siis korjaamista. Luulen, ettă hănen toivomansa avara kognitiivinen tulkinta ihmisestă, "joka omassa elämässäăn, toimintapiirissäăn toimii koko 'henkilökohtaisen historiansa', elämänkokemuksensa synnyttămien valintamekanismien perustalta'" (s. 32), sisăltăă tavallaan păhkinănkuoressa kognitiivisen psykologian nykyisen ristiriidan. Yhtäăltă kognitiivisen psykologian piirissă aletaan etsiă ihmiskuvaa, joka toimisi myős reaalimaailmassa, laboratorion ulkopuolella. Toisaalta tuo reaalimaailma, kulttuuri ja yhteiskunnallinen käytäntơ, jătetăăn yhă edelleen păăasiassa tarkastelun ulkopuolelle ja korvataan 'yksilonn elämänkokemuksen synnyttämillă valintamekanismeilla' - skeemoilla, sisäisillă malleilla, strategioilla jne. (vrt. Norman 1981). Tămă ristiriita ajaa kognitiivista psykologiaa ja toiminnan teoriaa hedelmälliseen vuoropuheluun.

\section{Lähteet}

Dawydow, W.W. 1977. Arten der Verallgemeinerung im Unterricht. Berlin: Volk und Wissen.

Engestrơm, Y. 1982. Perustietoa opetuksesta. Helsinki: Valtiovarainministerio - Valtion painatuskeskus.

Engestrơm, Y. (toim.) 1983a. Automaatio - ammattitaito - tietoisuuden kehitys. SAK:n Ammattiyhdistysopiston julkaisusarja No. 1.

Engeström, Y. 1983b. Kognitiivinen psykologia, oppiminen ja opetus - kognitivismin ongelma didaktiikan năkőkulmasta. Psykologia 18:3 (painossa).

Engeström, Y. 1983c. Opetus-oppimisprosessi aikuisopetuksessa. Vapaan sivistystyön XXVII vuosikirja. Porvoo - Helsinki - Juva: WSOY (painossa).

Engestrom, Y. 1983d. Teoreettinen suhde todellisuuteen ja oppimistoiminnan rakenne. Koulutyőntekijă 11:1, 31-33.

Kaajakari, M. 1983. Kiinnostava tietopaketti, mutta ... Aikuiskasvatus 3:1, 31-32.

Kuure, O. 1983. Kăsitteet ja todellisuuden haltuunotto. Koulutyőntekijä 11:1, 30-31.

Norman, D.A. 1981. Twelve issues for cognitive science. In Norman, D.A. (ed.) Perspectives on cognitive science. Norwood, N.J.: Alex Publishing Corporation, pp. 265-295. 